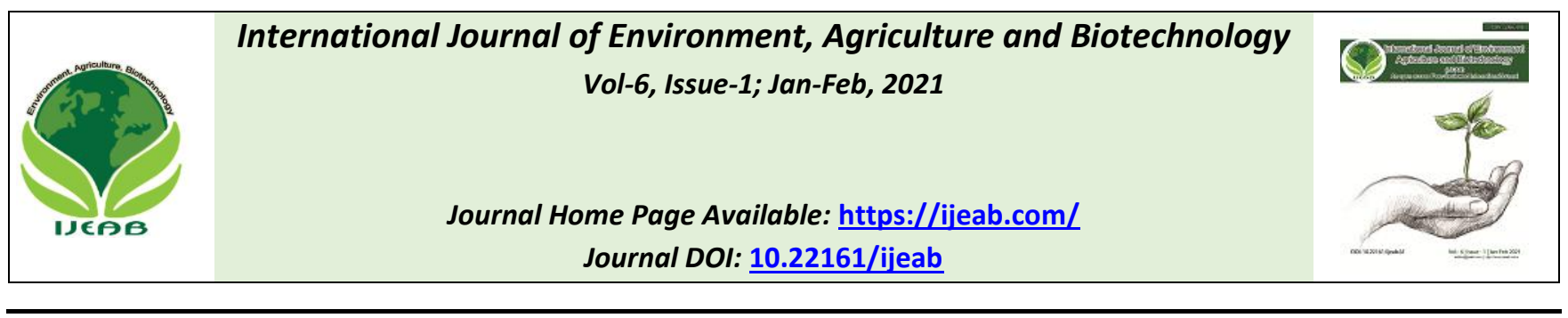

\title{
Dynamics of rubber cultivation in production systems in mountain zone of Côte d'Ivoire
}

\author{
Kouadio Y. D. M. ${ }^{1, *}$; Bahan F. M. L. ${ }^{2}$; Kouassi K. H. ${ }^{1}$; Keli Z. J. ${ }^{2}$ \\ ${ }^{1}$ Université Jean Lourougnon Guédé. UFR Agroforesterie; Département d'Agriculture et foresterie tropical; BP 150 Daloa, \\ ${ }^{2}$ Centre National de Recherche Agronomique (CNRA) Man-Côte d'Ivoire. 01 BP 1740 Abidjan 01 (Côte d'Ivoire). \\ *Corresponding author
}

Received: 03 Nov 2020; Received in revised form: 02 Jan 2021; Accepted: 08 Jan 2021; Available online: 14 Jan 2021 (C)2021 The Author(s). Published by Infogain Publication. This is an open access article under the CC BY license (https://creativecommons.org/licenses/by/4.0/).

\begin{abstract}
In Côte d'Ivoire, rubber cultivation is experiencing spectacular development. With land saturation in its traditional growing zones, rubber trees increasingly occupies new regions, including the west of the country. The objective of this study is to assess the place of rubber trees in the dynamics of production systems in the semi-mountainous region of western Côte d'Ivoire.

This study was carried out through a survey carried out among nearly 402 rubber planters from the Tonkpi region and part of the Guemon region. A semi-open questionnaire was used to collect data, particularly those relating to the profile of the farmer and the relationships that prevail between rubber trees and other crops.

Data analyzes have shown that the total area of production systems is 2758.12 ha, or 6.86 ha per farmer, and that of rubber trees is $1268.69 \mathrm{ha}$, or 2.41 ha per farmer. The average age of rubber fields is 8 years in 2019. Rubber plots were established between 1990 and 2019, of which 84 pc between 2007 and 2015. Planters use perennial polyculture in 76.87 pc of cases. Rubber cultivation occupies 46 p.c. of cultivated areas with coffee (45.63 p.c.) as the dominant previous crop. The rubber tree is grown in combination in 67.87 p.c. of cultural situations. Food crops are mostly (86.83 p.c.) used in associations.

Rubber cultivation occupies half of the production system in western Côte d'Ivoire and the relations which prevail between rubber trees and the other components of this system are, on the one part, relations of substitution of rubber for perennial cultures (Coffee) and on the other part relations of association with food crops.
\end{abstract}

Keywords-Rubber, Production systems, Previous crop, Cultural association, Man, Côte d'Ivoire.

\section{INTRODUCTION}

Since the independence of the Côte d'Ivoire in 1960, its agriculture has been dominated by the coffee-cocoa duo. The fluctuation in world prices of these two crops, coffee and cocoa, observed since the 1980s, has imposed on the State of Côte d'Ivoire a policy of diversification of export crops through the introduction of oil palm, coconut tree, cotton tree, cashew tree, sugar cane and rubber tree (Kéli, 2003). This latter speculation, initially developed by the large-scale farming sector, is now mainly carried out by small peasant farms (Ruf, 2009). First (1st) African producer of natural rubber since 1997, Côte d'Ivoire is now 6th in the world, with an estimated area of over 534,000 hectares for a production of 603,000 tons of dry rubber in 2017 (Kouassi, 2018).

Thanks to the improvement in the prices of natural rubber, the Côte d'Ivoire has defined a vast program of intensification and extension of rubber cultivation. This program, in support of smallholders, provided for the creation of 30,000 ha per year, with the objective of reaching a production of 600,000 tonnes of rubber by 2020 (Wahounou et al., 2013). But very quickly, the Côte 
d'Ivoire was confronted with a land saturation in the traditional areas of rubber cultivation. This has resulted in a remarkable extension of village rubber growing to new geographical areas such as the West (Gnagne et al., 2016a), which until then was a coffee-growing region and where there are already land problems linked to occupation one third $(1 / 3)$ of its area by mountains and boulders (ANADER, 2014 ; Keli, 2017).

The objective of this study is to determine the place of rubber trees in the dynamics of production systems in western Côte d'Ivoire.

\section{RESEARCH PROCEDURE}

\section{The site of study}

The study was carried out in four (04) departments of the Western Directorate of SAPH (Société Africaine de Plantations d'Hévéa) in the west of Côte d'Ivoire (Figure 1). These are the departments of Biankouma, Danané, Kouibly and Man. The coordinates of the study area are: 7 - 13'0 "North latitude, $7^{\circ} 40$ '60" West longitude and 329 $m$ altitude (Anonymous, 2017). The climate there is tropical humid, characterized by a single-mode rainfall, with a long rainy season from March to October (CNRAMan, 2017). The average annual rainfall from 2013 to 2017 was $1736.72 \mathrm{~mm}$. (CNRA-Man, 2018). The vegetation is dominated by numerous fallows of Chromolaena odorata and Alchornea cordifolia and of coffee and oil palm plantations (ANADER, 2014; Mameri, 2019). The relief is marked by a set of mountain ranges. In this rocky set of 500 to $1000 \mathrm{~m}$ altitude and with steep slopes, the highest summit is Mount Tonkpi which rises to $1189 \mathrm{~m}$ altitude (ANADER, 2014). The soils are mainly ferralsols (WRB, 2004). Their cultural suitability is generally good, apart from any physical constraint, breastplate and boulders (Bahan, 2016). The indigenous populations are of the Yacouba (Dan) ethnic group and the Touras. Non-natives from the Center, the North of Côte d'Ivoire and the sub-region represent $30 \%$ of the population (Ehua, 2000). The economy is based primarily on cash crops (coffee, cocoa, rubber and oil palm). Finally, the main food crops in the region are rice, cassava and maize.

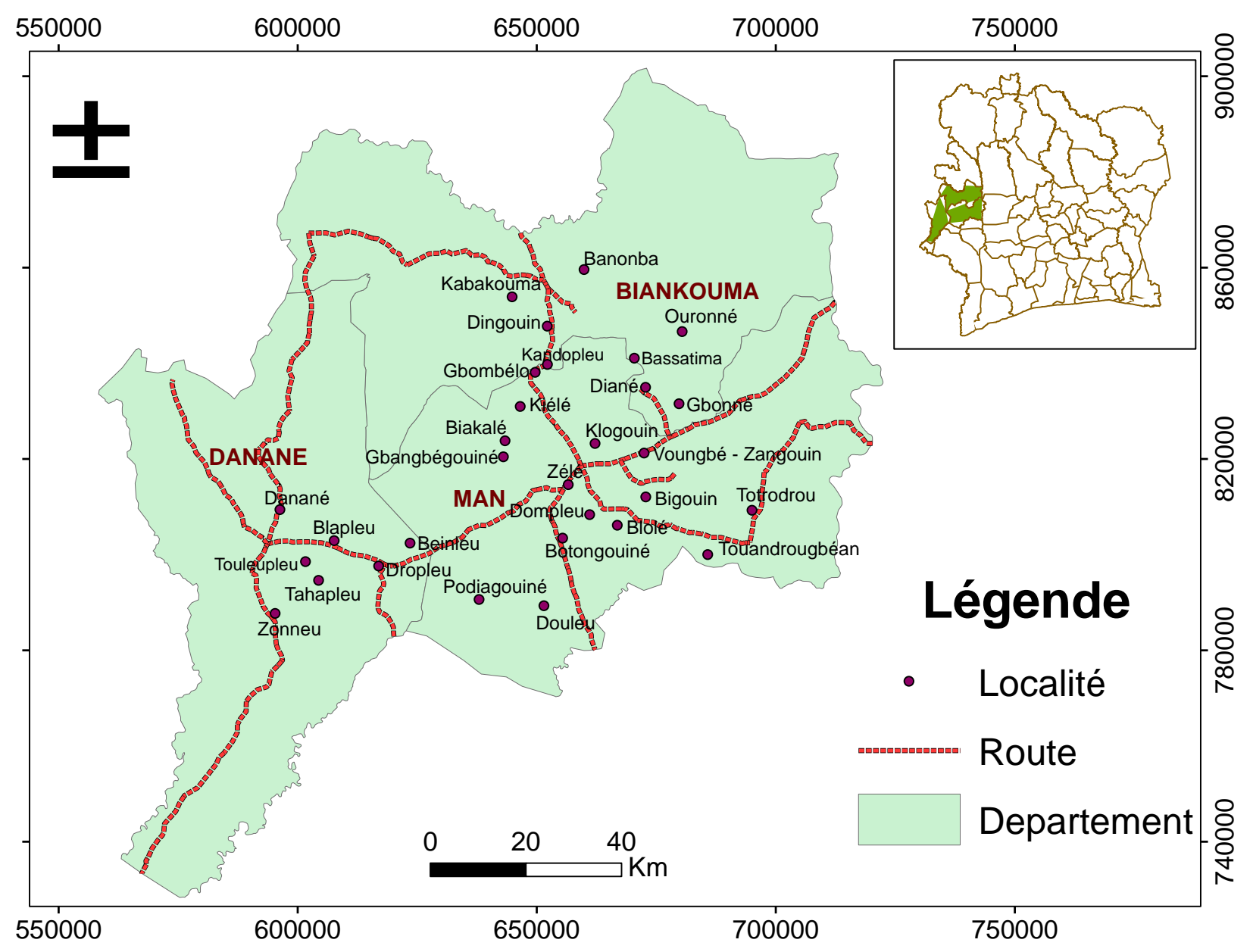

Fig.1: Survey area 


\section{Preliminary investigation}

A preliminary survey was carried out with resource persons from research and supervisory structures, in order to constitute a database necessary for sampling rubber farms. This database includes the number of rubber planters, the areas of the plots, and the years of creation of rubber fields in the Tonkpi region.

\section{Sampling}

The sample was obtained following a random selection carried out among rubber growers in each department so that it is representative. The formula below, which is the one recommended for calculating the size of a finite population sample, allowed us to determine the sample size for a confidence level $\mathrm{s}=95 \mathrm{pc}$ (very often used level), $\mathrm{t}=1.96$ and the " $\mathrm{p}$ " proportion to be estimated is nearly 50 p.c.

$$
n=\frac{1.96^{2} N}{1.96^{2}+(2 \epsilon)^{2}(N-1)}
$$

- N: Size of parent population

- $\mathrm{n}$ : Sample size for a parent population

- e: Margin of error that we give ourselves for the size that we want to estimate (for example we want to know the real proportion to within 5 p.c.)

\section{Data collect}

Data collection consisted of individual interviews with rubber growers and observations made in the fields. The data collected focused on the areas and the installation dynamics of rubber trees.

\section{Data analysis}

The data were entered on Excel 2010 software which was also used to determine the averages, frequencies and to produce the graphs. Descriptive statistics and crossover tables were performed on Stata SE 14 software.

\section{RESULTS}

The surveys focused on 402 rubber farmers, with 526 rubber farms, spread over 49 villages including 13 in the department of Biankouma, 11 in the department of Danané, 2 in Kouibly and 25 in the department of Man.
The villages visited are grouped into 12 different subprefectures.

\section{Place of rubber in production systems}

Analysis of survey data revealed that 76.87 p.c. of planters are using perennial polyculture. This rate differs from department to department. It is 89.39 p.c. for Biankouma, 90.43 p.c. for Danané, 88.24 p.c. for Kouibly and 64.22 p.c. for Man. Food crops are practiced by 74.63 p.c. of respondents. The total area of the rubber growers' production systems surveyed is 2758.12 ha with an average of 6.85 ha per farmer (Table II). The most important production systems per farmer are those of Danané (8.61 ha) and the weakest are those of Man (6.02 ha).

The total area of rubber tree plantations in this production system is 1268.69 ha (Table I). These areas vary from 0.33 to 20 ha with an average of 2.41 ha. The largest areas are in the department of Danané (2.8 ha per farmer) and the smallest in Kouibly (1.29 ha per farmer). The majority (73.77 p.c.) of rubber growers have plots of less than 3 ha (Figure 2). This proportion, which varies from one department to another, is between 69.41 p.c. (Man) and 94.74 p.c. (Kouibly).

Rubber cultivation thus occupies 46 p.c. of the farmland in the semi-mountainous region of Côte d'Ivoire (Figure 3). This rubber tree occupancy rate is higher in Man (52.51 p.c.) and lower in Kouibly (23.49 p.c.).

\section{Dynamics of the establishment of rubber plots}

The prospected plots were established between 1990 and 2019. The first two fields were established in 1990 in Man and Biankouma. These creations were followed by two other plots set up in 1997 in Danané. The big wave of establishment took place between 2007 and 2015 with 84 p.c. of field creation (Figure 4). The average age of the fields is 8 years in 2019 . 
Table I : Statistics of rubber cultivation in production systems in the semi-mountainous west of Côte d'Ivoire (2019)

\begin{tabular}{lccccc}
\hline Département & $\begin{array}{c}\text { Total } \\
\text { rubber } \\
\text { area }\end{array}$ & $\begin{array}{c}\text { Totale } \\
\text { exploitation } \\
\text { area }\end{array}$ & $\begin{array}{c}\text { Average } \\
\text { area } \\
\text { rubber }\end{array}$ & $\begin{array}{c}\text { Average area } \\
\text { exploitation }\end{array}$ & $\begin{array}{c}\text { Ratio Hévéa/Expl } \\
\text { (p.c.) }\end{array}$ \\
\hline Biankouma & 173,59 & 434,87 & 2,00 & 6,59 & 39,92 \\
Danané & 425,7 & 990,65 & 2,80 & 8,61 & 42,97 \\
Kouibly & 24,55 & 104,5 & 1,29 & 6,15 & 23,49 \\
Man & 644,85 & 1228,1 & 2,41 & 6,02 & 52,51 \\
Total & 1268,69 & 2758,12 & 2,41 & 6,86 & 46,00 \\
\hline
\end{tabular}

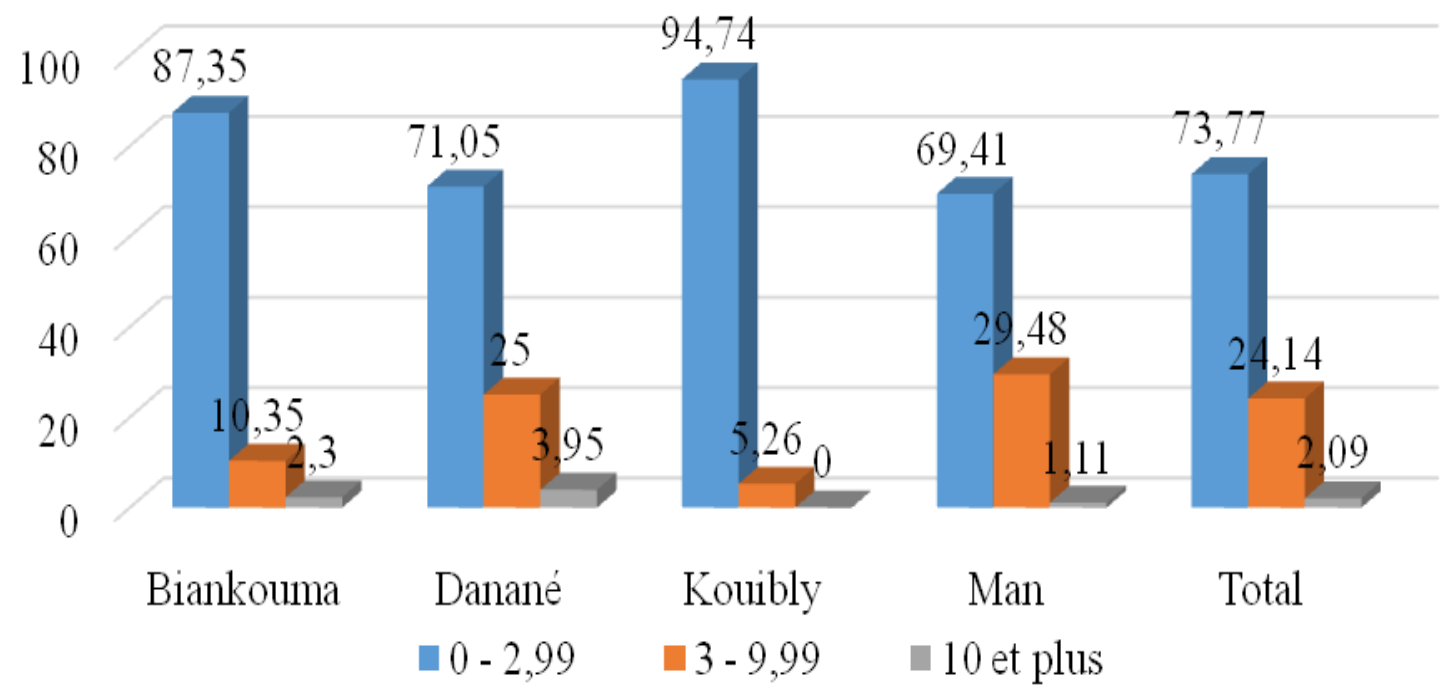

Fig.2: Surface area of rubber plots

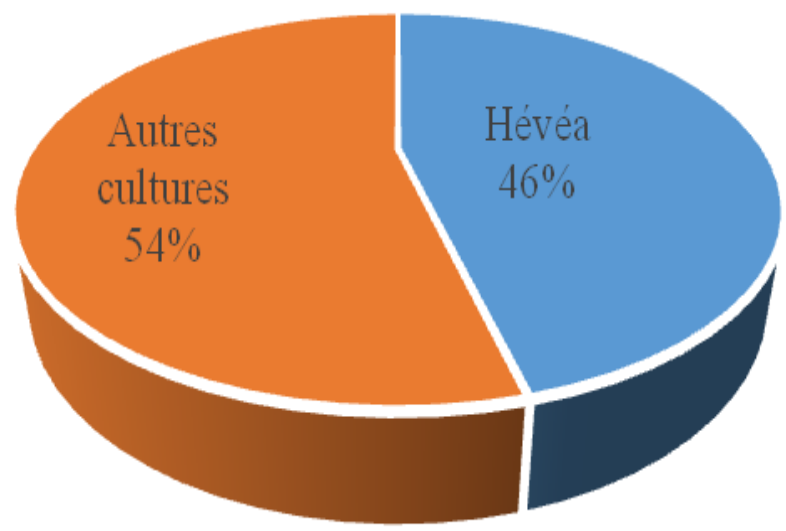

Fig.3: Place of rubber cultivation in the production system in the semi-mountainous west of Côte d'Ivoire 


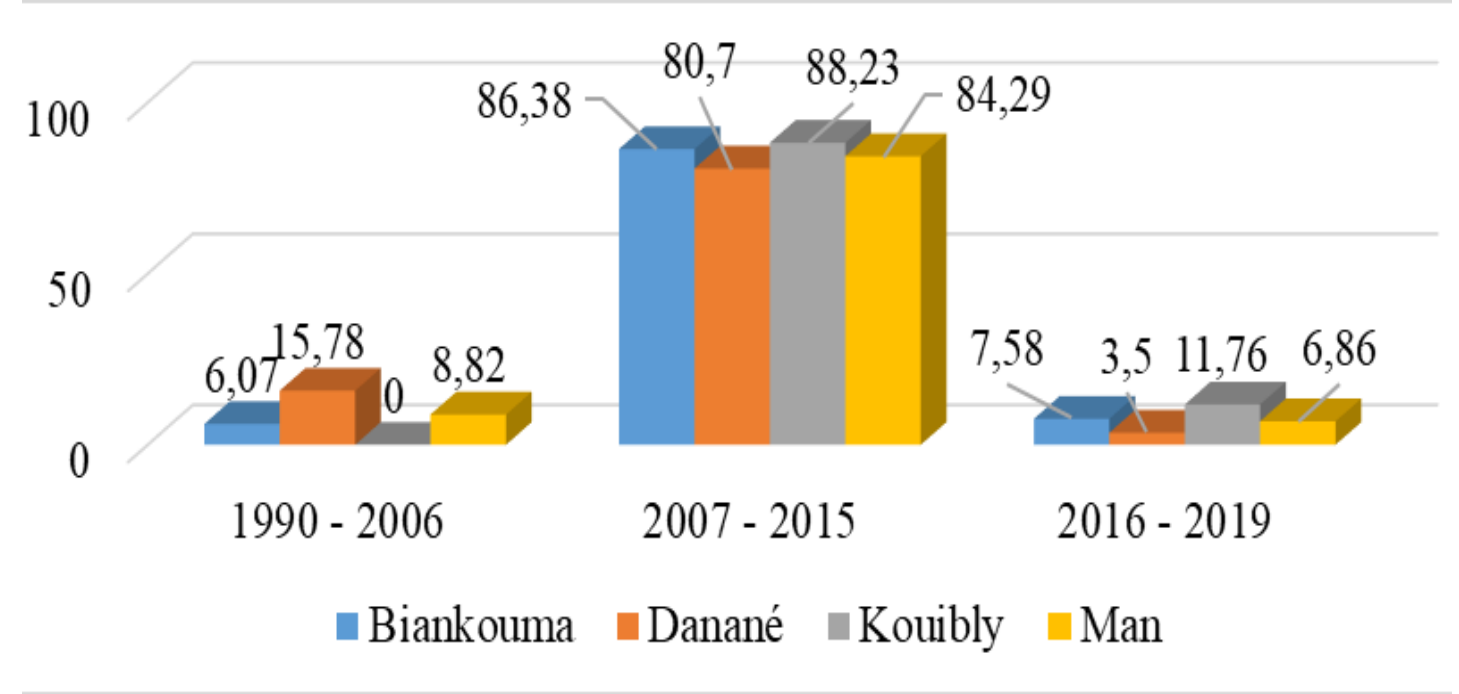

Fig.4: Installation period of rubber plots in the semi-mountainous west of Côte d'Ivoire (2019)

\section{Previous crops of rubber}

During the surveys, fallow, coffee, forest and crops were the four (04) previous crops observed. The previous dominant crop is coffee (45.63 p.c.) (Figure 5). However, the predominant crop precedent varies from one department to another. In Biankouma, fallow is the most important precedent $(48.28 \mathrm{pc})$ followed by coffee with 39.08 pc In Danané and Man, coffee is the majority precedent with respective rates of $49.34 \mathrm{pc}$ and $47.76 \mathrm{pc}$ of sown fields. The department of Kouibly presents a completely different configuration with fallow as the previous culminating crop (36.84 p.c.), followed by forest (31.58 p.c.). Coffee and other perennial crops each represent 15.79 p.c. of previous crops in the Kouibly zone. Regarding the age of fallows, it varies from one (01) to ten (10) years with an average of 4 years.

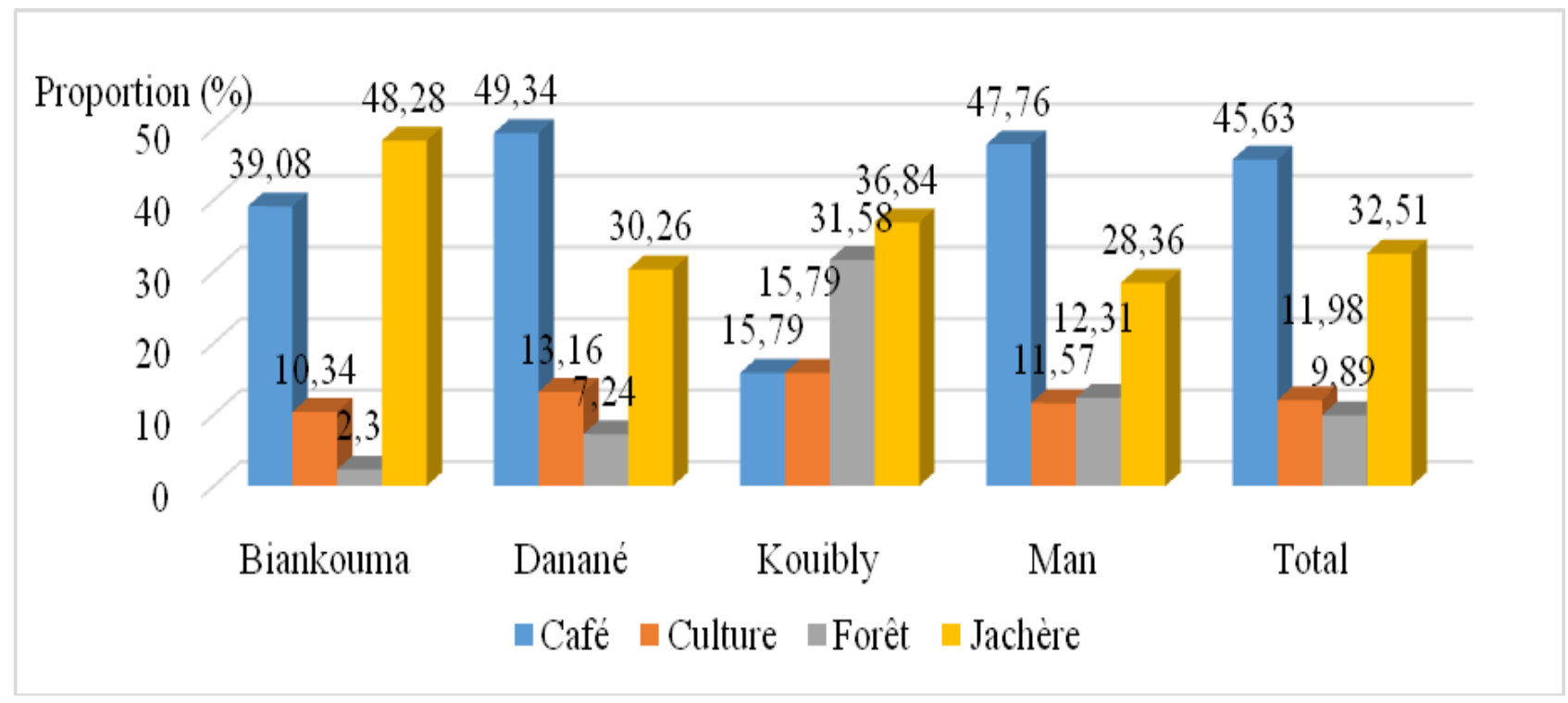

Fig.5: Previous crops of rubber plantations in the semi-mountainous west of Côte d'Ivoire (2019)

\section{Crop associations involving rubber}

The cultivation systems practiced relate, in 67.87 p.c. of cases, to associated cultures (Figure 5). The duration of associations with rubber varies from two (02) to ten (10) years, depending on speculation. Food crops (peanuts, rice, cassava, yam, beans, plantains and corn) are associated with rubber in 86.83 p.c. of cases. Export crops (Pineapple, Coffee, Cocoa and Cola) are associated with rubber trees in 7.56 p.c. of cases. Food-perennial combinations are associated with rubber trees in 5.6 p.c. of cases. The rubber 
associations in the semi-mountainous West have involved eleven (11) speculations, including seven (7) food crops and five (5) exports (Figure 6). These associations involve culture in 45.10 p.c. of cases and a combination of cultures in 54.90 p.c. of associations. The crops most associated with rubber in western Côte d'Ivoire are maize (58.82 p.c.) and rice (49.86 p.c.). In associations with rubber trees, food crops are laid out in bulk in the rows of trees.

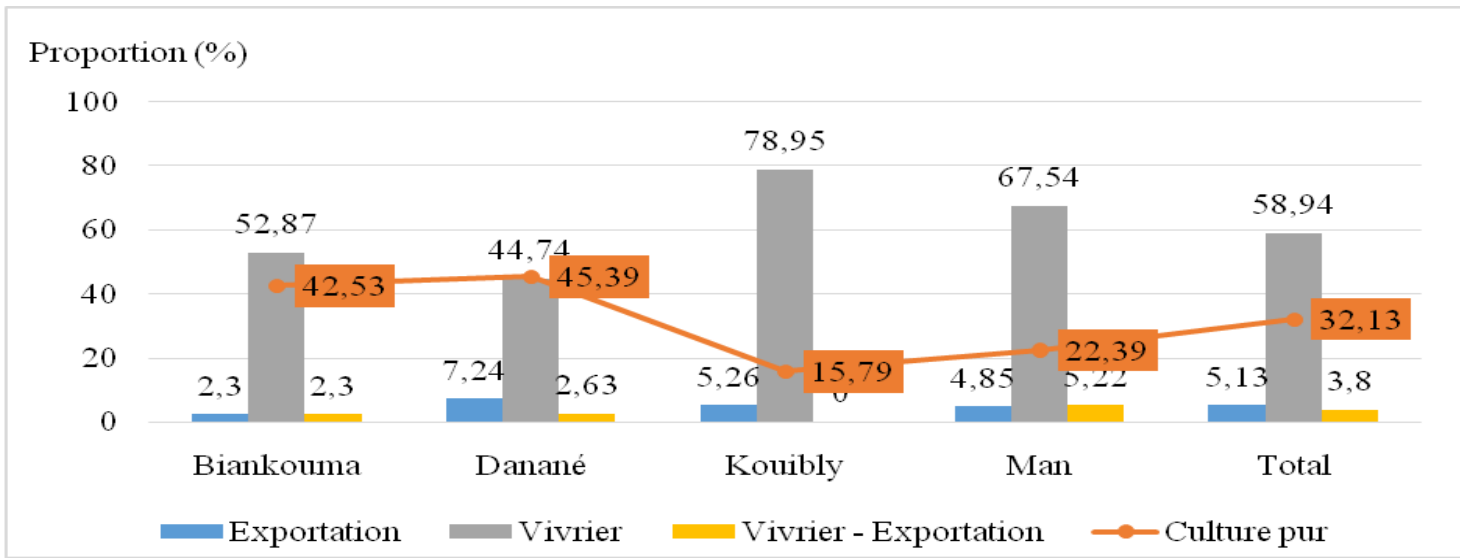

Fig.5: Associations with rubber

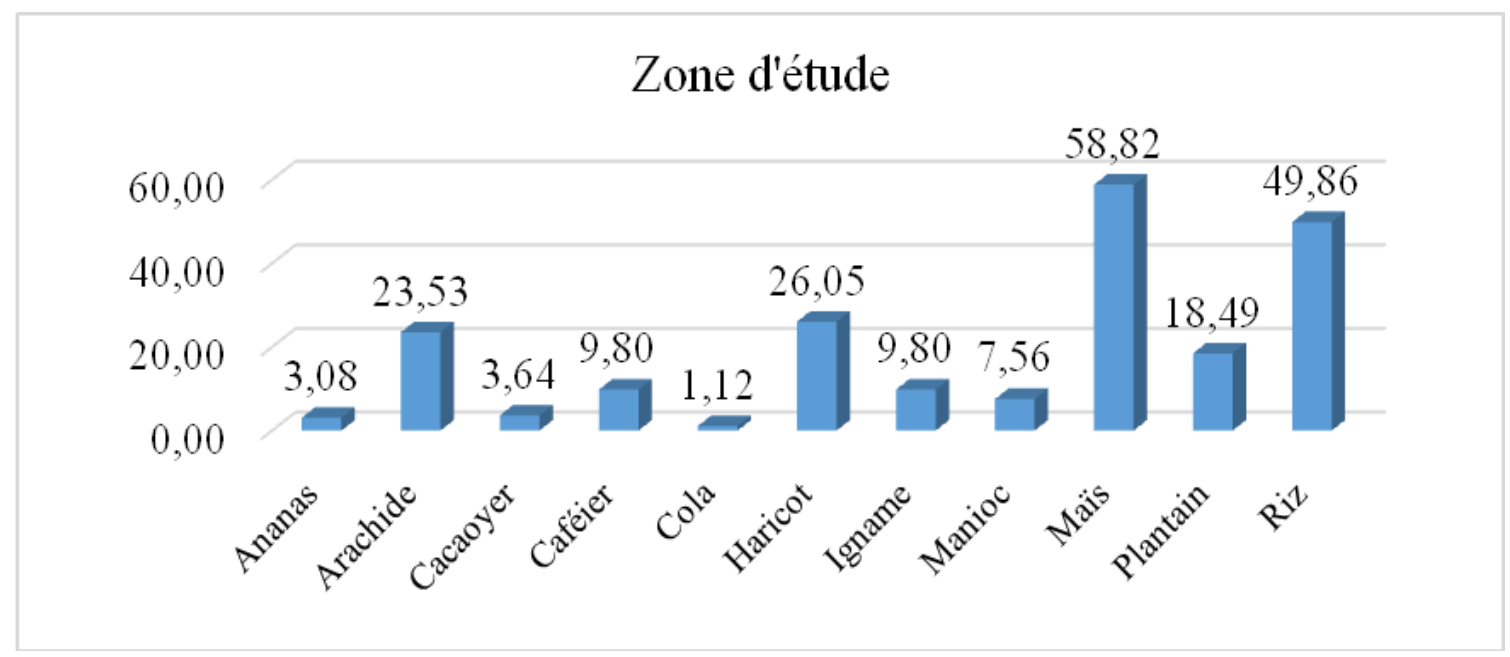

Fig.6: Crops associated with rubber

\section{DISCUSSION}

\section{Place of rubber in production systems}

Surveys show that the orientation towards rubber cultivation does not exclude the presence of other perennial crops, notably coffee, cocoa, oil palm, cashew and cola. The total surface area of the rubber growers surveyed is 2758.12 ha, or 6.86 ha per farmer. This area is greater than that of Akiés planters (Attiés) which is 3.4 ha (Ruf, 2018). Farms with only rubber as an export crop represent 23.13 p.c. of cases. According to Ruf (2018), young planters are more interested in rubber cultivation as they easily overcome six years of unproductivity. This could justify the fact that some growers only engage in rubber cultivation.
The total rubber area surveyed is 1268.69 ha. These areas vary from 0.33 to 20 ha with an average of 2.41 ha. This average area per farmer is lower than that of the Songon sub-prefecture, which is 3.91 ha (Kouamé, 2014). The majority (73.77 p.c.) of rubber growers have plots of less than 3 ha. This finding could be explained by the presence of rock massifs, which occupy a third of the study area and which considerably limit the area of cultivable land. Population growth could also have had an impact on the size of the plots (Keli, 2009). According to Koua et al., (2018), The size of cocoa plantations in the departments of Abengourou, Divo and Soubré are increased by plantations of 2-5 ha (51 p.c.). These results show that perennial crops are still the business of "small planters" (ICCO, 2015). This low proportion of arable land is probably linked to the non-mechanization of Ivorian agriculture. The small size 
of the orchards could also be explained by land saturation and the exhaustion of the country's forest reserves (Ruf and Allangba, 2001; FAO, 2007; Aka et al., 2013). Rubber cultivation occupies 46 p.c. of the farmland in the semimountainous region of Côte d'Ivoire. The highest rate was observed in Man (53.07 p.c.) and the lowest in Kouibly (20.54 p.c.). Coffee and cocoa occupy 26.44 pc and 15.26 pc respectively. ancient cultures. According to ICCO (2014), L'hévéa is emerging as a diversification crop again in 2017 , despite the level of land saturation.

\section{Dynamics of the establishment of rubber plots}

The prospected plots were established between 1990 and 2019. Thus the age of the rubber orchard in the semimountainous region of Côte d'Ivoire is between 1 and 30 years. The average age of the fields is 8 years in 2019. On the other hand, the entry of rubber cultivation in Côte d'Ivoire dates from 1953 by agro-industrial companies through large farms (Losch, 1983; Canh, 1999; Hirsch 2002; Ruf 2013; Kouamé 2014). In 1978, rubber cultivation integrated family farming through small farms (Keli et al., 1997; Ruf, 2009). This shows that the cultivation of rubber trees in western Côte d'Ivoire is young. Given the operating life of 30 to 40 years, rubber trees could have a promising future in the west of the Ivory Coast.

Also, the first two fields were established in 1990 in Man and Biankouma. These creations were followed by two other plots set up in 1997 in Danané. According to Ruf (2009), the Ivory Coast owes the doubling of its production in 8 years to the village sector whose performance is approaching each year the production threshold of industrial plantations. Thus, the big wave of establishment is between 2007 and 2015 with 84 p.c. of fields created. According to Koulibaly (2016), rubber cultivation has increased dramatically with an increase of 479.38 p.c. in its recorded areas. This would be due to the price of the kilogram of rubber which increased from 2001 to 2010. It went from three hundred and seventy-five (375) FCFA to one thousand $(1,000)$ FCFA. According to Akmel (2018), this state policy aimed to encourage actors, so that they become more involved in rubber production. This is corroborated by the increase in production to 603,000 tonnes in 2017 (Kouassi, 2018). Furthermore, the rationalization of income created by rubber cultivation due to the monthly payment of production could justify the massive investment of young people in rubber. Also, rubber farmers participate in the restoration of the green fabric.

\section{Previous crops of rubber}

The previous dominant crop is coffee with a proportion of 45.63 p.c. This shows that rubber trees are in the process of replacing coffee. The substitution of rubber for other export crops has also been revealed by surveys in the Dabou region in Côte d'Ivoire (Akmel, 2016). The phenomenon of substitution of rubber tree plantations for old cocoa or coffee trees is not new (Ruf, 2009). The development of rubber cultivation has taken place at the expense of other perennial crops in Songon and mainly of oil palm. Also, $12 \%$ of farmers replaced cocoa and coffee farms with rubber (Kouamé, 2014). According to Aguilar et al. (2003) cited by Akoua et al. (2018), the small size of cocoa plantations in the departments of Abengourou, Divo and Soubré would be linked to the abandonment and conversion of some old cocoa trees into palm oil plantations. and rubber (Ruf and Allangba, 2001; Kassin, 2009). Land blockades and the growing interest in rubber cultivation could account for this trend. However, the predominant crop precedent varies from one department to another. In Biankouma, fallow is the most important precedent (48.28 p.c.). The department of Kouibly presents fallow as the previous culminating crop (36.84 p.c.), followed by forest (31.58 p.c.) then coffee (15.79 p.c.). Regarding the age of fallows, it varies from one (01) to ten (10) years with an average of 4 years. The fallows are between 5 and more than 10 years old and belong to adults. One third of the mainly young farmers have no land reserves. The low percentage of the previous forest corroborates the observations on the decline of forest massifs in Côte d'Ivoire. Forest areas, which amounted to 15 million ha in the 1900s (SODEFOR, 1996) represented only 2 million ha in 2007 (FAO, 2007).

\section{Crop associations involving rubber}

The cultivation systems used relate, in 67.87 p.c. of cases, to associated cultures. This rate is lower than that of the Songon sub-prefecture which is 85.43 p.c. of farmers surveyed (Kouamé 2014). Cultural association could allow diversification of production and sources of income. However, according to the farmers surveyed, the cropping association in the semi-mountainous region of Côte d'Ivoire is motivated by the simultaneous maintenance of associated crops (48.61 pc) and the lack of land (44.44 pc). Benefits of this practice of combining annual crops with trees may include food security for households, income generated from the sale of both products, weed control and better use of cultivated resources (Balogoun et al., 2014). According to Kouamé (2014), To fill the land shortage, the populations practice the association of cultures. The duration of associations with rubber varies from two (02) to ten (10) years, depending on speculation. In fact, during the immaturity period of the rubber tree (6 years), producers form associations to ensure food security during this period, create sources of income and implement cultivation techniques likely to help the growth. 
maintenance of the rubber tree. In addition, intercropping brings organic matter to the soil through the decomposition of crop residues. Monoculture with leguminous cover (often Pueraria) between the rows of rubber trees is a satisfactory practice from an agronomic point of view thanks to the fight against erosion and against weeds, supply of nitrogen and maintenance of humidity (IRRDB, 1996). The Hévéa brasiliensis species is actually cultivated in association with other domesticated species such as cover legumes (Pueraria phaseoloïdes, Centrosema pubescens, etc.), food and industrial species (Obouayeba et al., 2016). The crops set up on the whole of the young plot, accept a valuation of the land while guaranteeing a maintenance of the space beneficial to the development of the young rubber plants. The crops grown depend on the eating habits of the farm manager and his family. These are usually mixtures of species including plantain, corn, macabo, peanut, pistachio, yam and sweet potato. (Thierry, 2005). The rubberwood associations in the semimountainous West have involved eleven (11) speculations, including seven (7) food crops and five (5) exports. These associations involve culture in 45.10 p.c. of cases and a combination of cultures in 54.90 p.c. of associations. Associated food crops meet the self-consumption needs of growers and / or marketing (Kéli et al., 2006). Thus, food crops (peanuts, rice, cassava, yam, beans, plantains and corn) are associated with rubber in 86.83 p.c. of cases. In Songon, 48.27 p.c. of plots of food crops (maize, yam, vegetables) and mainly cassava were also planted with rubber in these two localities (Kouamé, 2014). The crops most associated with rubber in western Côte d'Ivoire are maize (58.82 p.c. of associations) and rice (49.86 p.c. of associations). This is corroborated by the fact that 73.25 p.c. practices the association with the objective of directly consuming the product of the harvest. Rice and corn therefore dominate the associations in Man. However, cassava, one of the staple foods in the region, is not associated with rubber, presumably for fear of the spread of root rot caused by the genus Fomes. Cassava is a vector of this disease. Therefore, the rubber-cassava combination has long been discouraged. However, recent work by the CNRA, led by Boko in 2012, has shown the possibility of leading such a cultural association. Cassava should be planted at a distance of at least $1.5 \mathrm{~m}$ from the rubber tree line. In addition, it was observed that the food crops associated with rubber trees were sown or planted in bulk, not respecting the technical recommendations of the research. In rubber associations, food crops are arranged in bulk in the rows of trees. Export crops (Pineapple, Coffee, Cocoa and Cola) are associated with rubber trees in 7.56 p.c. of cases. Food-perennial combinations are associated with rubber trees in 5.6 p.c. of cases. These associations are not permanent because they only last 5 years. Hevea is intended to replace associated cultivation as is the case in Brazil, where rubber-coffee associations only last about ten years (Penot \& Ollivier, 2009). The rubber tree can be associated with fruit trees and forest species; cases of the Philippines, Malaysia, Thailand, Brazil; with tea; the case of China; rattan; cases of Malaysia and the Philippines; and the cocoa tree; cases of Côte d'Ivoire, Gabon, Brazil and Vietnam (Ruf et al., 2006; Penot \& Ollivier, 2009).

\section{CONCLUSION}

The objective of the study was to assess the place of rubber trees in the dynamics of production systems in western Côte d'Ivoire. The study showed that 76.87 p.c. of planters are using perennial polyculture. The total surface area of the rubber growers' production systems surveyed is 2758.12 ha with an average of 6.85 ha per farmer and that of rubber trees is 1268.69 ha or 2.41 ha per farmer. Rubber cultivation, which thus occupies 46 pc of sown areas, could be considered as a substitute crop for old crops. The age of the rubber orchard is between 1 and 30 years with an average of 8 years in 2019. The great wave of he establishment is between 2007 and 2015 with 84 pc of field creation. Considering the juvenile age of rubber trees in the west, there could be a bright future.

In perspective, effective associations should be determined for optimal use of agrarian space. This study will overcome the problems of substituting rubber for other crops in the study area with a view to diversified and sustainable agriculture.

\section{REFERENCES}

[1] Aguilar P, Paulin D, Keho Y, N'kamleu G, Raillard, A, Deheuvels O, Petithuguenin P and Gockowski J. (2003). The evolution of cocoa orchards in Côte d'Ivoire between 1995 and 2002. In: Proceedings of the 14th international conference on cocoa research. October 18-23, 2003. Accra, Ghana, p.1167-1175.

[2] Aka N, Bamba SB, Soro G, Soro N (2013). Hydrochemical and microbiological study of layers of alterites in a humid tropical climate: Case of the department of Abengourou (south-eastern Côte d'Ivoire). Larhyss Journal 16: 31-52.

[3] Akmel M. S., (2016). ; Socio-economic issues and constraints related to rubber cultivation in Jdjukru country in the region of Dabou (Ivory Coast); European Scientific Journal; vol.12, pp 431-450.

[4] Akmel M. S., (2018). Socio-economic challenges of rubber cultivation and risk of food insecurity in Odjukru country in the Dabou region (Côte d'Ivoire); TROPICULTURA, 2018 , 36,2 , pp 425-434)

[5] ANADER (2014). Monograph report (Internal document). ANADER Man, $23 \mathrm{p}$. 
[6] ANADER, (2014). Monograph report (Internal document). ANADER Man, $23 \mathrm{p}$.

[7] Anonymous (2017). https: //fr.wikipedia.org/wiki/Man (Côte_dp.c.27Ivoire). Accessed on 04/05/2017

[8] Anonymous, (2007). https: //fr.wikipedia.org/wiki/Man (Côte_dp.c.27Ivoire). Accessed on 04/05/2017

[9] Bahan F., (2016). Annual report of research activities 2015; Rice program. CNRA Man (Internal document). $43 \mathrm{p}$.

[10] Balogoun I., A. Saïdou, E. L. Ahoton, 1. G. Amadji, c. B. Ahohuendo, I. B. Adebo, S. Babatounde, D. Chougourou, H. Adoukonou-sagbadja and A. Ahanchede; (2014). Characterization of cashew-based production systems in the main growing areas in Benin. African Agronomy 26 (1); pp $9-22$

[11] Boko C. \& Tahouo O., (2012). Combine food crops with rubber trees to diversify sources of income in Côte d'Ivoire. CNRA-2012, Department of Innovations and Information Systems, $52 \mathrm{p}$.

[12] CNRA-Man, (2017). CNRA Man meteorological station (rainfall 2016).

[13] CNRA-Man, (2018). CNRA Man meteorological station (rainfall 2017).

[14] Ehua M., (2000). Handover report, MINAGRA / DRG, Gagnoa. Ivory Coast, 13 p.

[15] FAO., (2007). The State of World Fisheries and Aquaculture, Rome. Italy, $131 \mathrm{p}$

[16] Gnagne Y. M., Elabo A.E.E., Wahounou P. J., Obouayeba S., (2016a.) Marginality factors for rubber farming in the old cocoa loop, in central-eastern Côte d'Ivoire. IRRDB WORKSHOP- 28-29-30 / 09/2016

[17] Hirsch R. (2002). Ivorian rubber cultivation after the privatizations and liberalization of the sector. Balance sheet essay. Paris, AFD.

[18] ICCO (2014) Report of the World Cocoa Conference 2014. Amsterdam, 9-13 June 2014. 17 p.),

[19] ICCO (2015). What are the effects of intensive commercial production of cocoa on the environment? Westgate House W5 1YY, United Kingdom. ICCO Annual Report. 25p.

[20] IRRDB, (1996). Symposium on farming system aspects of the cultivation of natural rubber (hevea brasiliensis), IRRDB, Beruwala, November 1996. 150 p.

[21] Kassin K. E. (2009). Studies of pedoclimatic conditions for cocoa replanting in the Center-West of the Ivory Coast: case of the Divo and Gagnoa departments. Single Doctorate Thesis from UFR STRM, University of Cocody - Abidjan, Côte d'Ivoire. 112p.

[22] Kéli Z. J., (2003). Second generation program; Commission: Export crops. CNRA working document, $139 \mathrm{p}$.

[23] Kéli Z. J., (2009). The regional management of the CNRA in Man in a few words and figures, $12 \mathrm{p}$.

[24] Kéli Z. J., (2017). The regional management of the CNRA in Man in a few words and figures, Internal document; $12 \mathrm{p}$.

[25] Kéli Z. J., Boko C., Assiri A. A., Hubert O., Obouayeba S. \& Doumbia A., (2006). How to associate food crops with rubber trees in the Ivorian peasant environment. Department of research programs and development support - Department of innovations and information systems CNRA, 2 p.
[26] Kéli Z.J., Kpolo, D.M., Déa, G.B., Boa, D. and Allet-Don A. (1997). Rubber farming in Côte d'Ivoire: Current situation and prospects. Plantations, Research, Development 4 (1),

[27] Koua SH, Coulibaly NAM Da., Alloueboraud WAM (2018), Characterization of orchards and cocoa diseases in Côte d'Ivoire: case of the departments of Abengourou, Divo and Soubré) (Journal of Animal \& Plant Sciences, 2018. Vol. 35, Issue 3: 5706-5714 Publication date 03/31/2018, http://www.m.elewa.org/JAPS; ISSN 2071-7024 5706

[28] Kouame D. P. E. (2014); The development of rubber farming, agricultural and land tenure changes in Songon; European Scientific Journal edition vol.10, No.35 ISSN: 1857 - 7881 (Print) e - ISSN 1857- 7431 39; 14p.

[29] Kouassi B. S. T., 2018. Policy, development and sustainability challenges of natural rubber in Ivory Coast, International Rubber Conference and IRRDB Annual Meeting, 22-24 October 2018, Abidjan, Ivory Coast, 16 p.

[30] Koulibaly T. 2016. Development of rubber cultivation in Côte d'Ivoire: threats or opportunities for food crops: Case study of the regions of Daloa and Abengourou, IRRDB regional workshop, September 28-30, 2016, Yamoussoukro, Ivory Coast, $25 \mathrm{p}$.

[31] Losch B. (1983). Village rubber cultivation in Côte d'Ivoire. DESS thesis, University of Montpellier I, $120 \mathrm{p}$.

[32] Mameri C., (2019). Agricultural practices in the mountainous region of Côte d'Ivoire. European University Editions. 69p.

[33] Obouayeba S., Boko A. M. C., Soumahin E. F., Elabo A. A. E., Dea G. B., N'guessan B. E. A., Kouamé C., Zéhi B. \& Kéli Z. J., (2016). Stable rural production systems based on (Hevea brasiliensis Muell. Arg.): Synthesis of forty years of work; IRRDB WORKSHOP- 28-29-30 / 09/2016

[34] Penot E. \& Ollivier I., (2009). The rubber tree in association with perennial, fruit or forest crops: some examples in Asia, Africa and Latin America. Wood and forest of the tropics No 301 (3), pp 67-82.

[35] Ruf (2013). The rubber boom in Côte d'Ivoire. CIRAD report to IFC $48 \mathrm{p}$

[36] Ruf F, Allangba K (2001). Cocoa plantation and replanting decisions. The case of Baoulé migrants in Oumé (Ivory Coast). In: R.Y Assamoi, K. Burger, D Nicolas, F. Ruf and P. de Vernou, eds. The future of perennial crops. November 5-9, 2001. Yamoussoukro (Ivory Coast): BNETD \& CIRAD. 36p.

[37] Ruf F., 2009. The adoption of rubber cultivation in Côte d'Ivoire. Price, imitation and ecological change. INRA / SFER / CIRAD, $22 \mathrm{p}$.

[38] Ruf F., Deheuvels O., Ake Assi L. \& Sarpong D., 2006. Intensification in cocoa cropping systems: is agroforestry a solution for sustainability? The Case of Manso Amenfi, Western region, Ghana. In: Fifteenth International Conference on Cocoa Research, San José, Costa Rica, 9-14 October 2006, vol. I, pp 355-364

[39] Ruf, F. 2018. Politico-military and climatic crises in Côte d'Ivoire. From cocoa to cashew nut, from forest income to animal manure. Tropicultura; pp 281-298 
[40] SODEFOR., 1996. Development plan of the classified forest of Bouaflé. Ministry of Agriculture and Animal Resources, pp 3-61.

[41] Thierry M., (2005). Adapt the management of rubber tree plantations to the diversity of village farms (Case study in Cameroon). Doctoral thesis from the Institut National Agronomique Paris-Grignon, France, 302 p.

[42] Wahounou P. J., Mpika J., Kouadio J. M., Adiko A., Zakra N. and Tahouo O. (2013). Diseases and pests of rubber trees in production areas in Côte d'Ivoire. CNRA-2013, Department of Innovations and Information Systems, $54 \mathrm{p}$

[43] WRB, (2014). A frame work for international classification, correlation and communication. Food and Agriculture Organization of the United Nations. Rome: IUSS / ISRIC / FAO; (World Soil Resources Reports, 106). 